\title{
Language policy and planning for Latinos in Indiana: A case study
}

\author{
Colleen E. Chesnut
}

\begin{abstract}
In Indiana and many other areas of the Midwest, Latino populations have recently experienced quite rapid growth. This study will focus on how Indiana's state and local institutions, including government agencies, schools, and community organizations have responded to expansion of Latino communities, examining evidence of language policy and planning in these responses. An epistemological framework outlining the parameters of language policy and planning will be provided, as well as a brief historical narrative to set the context for Latinos settling in Indiana. Demographic data and document analysis reveal both the salience of this research for a growing Latino population and the current availability of resources and information about policy around language planning for this group. Findings illustrate that English remains the primary lingua franca for Indiana, though some evidence indicates scattered efforts to reach out to Latino citizens in Spanish through a variety of means. This research contributes to a growing body of literature on experiences of Latinos in the Midwest and policymakers' efforts to better serve the needs of these growing communities.
\end{abstract}

\section{Introduction}

With ever-increasing frequency across the largely rural and somewhat sparsely populated state of Indiana, Latino families are making their homes. In both small and large communities formerly accustomed to the homogeneity of a white Englishspeaking majority, native Spanish-speaking men, women, and children are living, working, and attending schools. This presents a relatively new challenge to state and local governments, school districts, employers, and community organizations in terms of language planning and policy implementation. This case study will explore the language policy context of Indiana as it affects the Latino population. For the purposes of this study, the term "Latinos" will be employed to mean persons of descent or origin from Latin America, including Mexico, and the Spanish-speaking Caribbean, Central American, and South American nations.

To begin with, the study will be framed by theoretical definitions of language planning and language policy as described by Cooper (1989). Within this framework, the history of Latinos migrating to and settling in Indiana will be discussed. Following this will be an exploration of the current state of planning and implementation of language policies, both overt and covert, at the state and local levels. Finally, the implications of these policies and practices for native Spanish- 
speaking Latinos in Indiana will be outlined. Primarily a review of existing research and data, the main purpose of this study is to act as a guide for future research into effective language planning and policy practices for those interested in serving the needs of Indiana's Latino population.

\section{Epistemological Framework}

In order to create a framework for this investigation, definitions designated by Cooper (1989) will be employed for some of the terms and ideas around language planning and policy to be used consistently throughout. Since this is an examination of language planning within a state, rather than at a national level, the definitions used will be rather broad and applicable to a variety of activities. Thorburn states that "[language planning] occurs when one tries to apply the amalgamated knowledge of language to change the language behavior of a group of people" (quoted in Cooper, 1989, p. 30). In this case, the target group of people is the Latino population of Indiana and those who seek to "apply the amalgamated knowledge of language" may be government officials, educators, community organizers, members of the media, employers, or any other number of people who make decisions about language use. Their "knowledge" may emanate from a vast array of sources and will likely contradict the knowledge and beliefs of others seeking to affect language use. This broad definition of language planning will allow for an investigation of the many different ways in which this concept can manifest at the state and local levels to influence the Latino community.

From this and other basic definitions of language planning, Cooper (1989) identifies three branches of the field: corpus planning, acquisition planning, and status planning. This study will focus specifically on acquisition planning and status planning, as they are likely more salient to Latinos coming to Indiana with an already well-established and recognized native language. Cooper (1989) defines status planning as the decisions and actions that will influence the functionality of a language in relation to other languages. The two languages juxtaposed in this case are, of course, Spanish and English. To illustrate with a basic example, status planning would be involved when a local business decides to provide information to customers in both English and Spanish. By providing the information in Spanish (the minority language) as well as English (the majority language), this business would potentially be changing the status of Spanish within the community, as they affirm that Spanish is also a legitimate form of communication within their business.

On the other hand, acquisition planning is defined as the decisions and actions that will influence the number of users of a language (Cooper, 1989). Again, the focus will be on Spanish and English acquisition, both for Latinos in Indiana and for non-Latinos who live alongside them in their communities. Acquisition planning often manifests in school settings, where classroom teachers and ESL instructors work together to plan for ways to help native Spanish-speaking students learn English. Narrowing the frame of language planning to focus on status planning and acquisition planning, specifically, will be useful for comparisons of communities and practices. 
In addition to defining language planning and the specific aspects of the concept to be explored here, another term defined in Cooper's text, language policy, will be utilized frequently. Cooper (1989) repeatedly refers to language policies as proposed solutions to "language problems," but this designation seems somewhat troubling in the context of the Latino population, inferring that Spanish speakers' native language is a deficiency rather than a resource. This research will give preference to Prator's definition of language policies as "decisions concerning the teaching and use of language and their careful formulation by those empowered to do so, for the guidance of others" (quoted by Cooper, 1989, 31). This definition classifies language policies as "decisions" rather than solutions to perceived problems, suggesting that all language differences may not necessarily be problematic. Additionally, language policies may be official, found written into legal documents, or they may be more covert, emerging from a set of common practices to become standard procedures. Using this definition and remaining mindful that language policies may present as overt or covert, the following case study will explore language policies that govern the use of both English and Spanish in a variety of contexts and from a historical perspective within Indiana's communities and institutions.

\section{Research Questions}

By delving into the available research and data surrounding Latinos' experiences with language planning and policies in Indiana, this research will address several questions. The primary question determining the course of this case study is how do language planning, policies, and practices in Indiana affect native Spanish-speaking Latinos? Stemming from this are several secondary questions whose answers will help to focus the answers to the primary question. These secondary questions concern the historical context of Latino immigrants to Indiana and how their situation has evolved over time: which people, agencies, or organizations are responsible for planning and implementation of language policies affecting Latinos in Indiana, and what kinds of language policies, both overt and covert, exist? In order to address these questions, the experiences of Latinos in Indiana will be examined in historical and present-day contexts, using secondary research as well as existing demographic data. Subsequently, this research will focus on other actors playing roles in language planning and policy for Latinos, including what kinds of policies exist and in what forms.

\section{History of Latinos in Indiana}

\section{Early Experiences of Latinos in the "Region": 1919-1970}

Due to its location in the heart of the Midwest, Latino immigration to Indiana has occurred later and in distinct patterns from the migration of Latinos in other states situated closer to the US's southern border. While a significant amount of research exists on the early experiences of Latinos in the heavily industrialized northwest region of the state, there is little documentation on the early presence of Latinos in the central, southern, and more rural parts of the state. The first Latinos to arrive in significant numbers in Indiana were of Mexican origin, though many of them may have previously been living in the southwestern US for a number of years. They 
came beginning in 1919 and throughout the early 1920s to work for US Steel in Gary and Inland Steel in East Chicago, initially serving as strikebreakers during the Great Steel Strike of 1919. By 1928, workers of Mexican descent comprised 9\% of the workforce for US Steel. At first, men came to work in the steel mills, leaving their families behind either in the Southwest or in Mexico. However, many wives and children eventually joined the men, and communities of Mexican-Americans began to emerge and thrive, establishing businesses and community organizations (Escobar, 1987; Garcia \& Cal, 1987; Lane, 1987). As the Latino community in this area of northwest Indiana, commonly known as "the Region," grew in numbers and strength, issues of language and cultural differences became more salient, especially for the Latinos living and working in predominantly white and English speaking environments.

Several of the community organizations founded in the early years of Latinos' migration to the Region concerned themselves, among other things, with issues of language planning. These groups were often termed mutualista, or mutual aid organizations, and by 1929 there were 11 distinct Mexican mutualista organizations in the Region (Rosales \& Simon, 1987). Los Obreros was one of the most prominent of such groups, founded in 1925 as an organization to promote Catholicism, celebration of the Mexican community, patriotism (loyalty to both Mexico and the US), and assimilation to some US values, such as the importance of hard work (Garcia \& Cal, 1987). Although members of Los Obreros were accused of being elitist, as many of them were more educated and fluent in English than some of the more recent Mexican-American immigrants to the area, they made efforts to help the community members maintain their use of Spanish. They published a free weekly newspaper called El Amigo del Hogar, printed in Spanish, with columns on local news, household advice and other items of interest to the Spanish-speaking community. This is the earliest evidence of Latinos in Indiana attempting to maintain their cultural identities, including native language, through mutual aid groups that supported the distinct needs of Mexican-Americans.

Unfortunately, with the stock market crash of 1929 and the following Great Depression, Mexican-American steel workers in the Region, along with many others, lost their jobs. During this era, the Mexican-American communities in this area of the state shrank, as many men and their families left to find work elsewhere or returned to Mexico (Escobar, 1987). As the population shifted, the mutualista organizations, including Los Obreros, also faded away (Garcia \& Cal, 1987). However, while the communities no longer thrived as they had during the early 1920s, significant enough portions of the Mexican-American population remained in the Region so that their communities did not vanish entirely.

While the Mexican-American community in the Region may have diminished somewhat during the Depression, World War II and its end brought new vitality and change. What was previously a fairly homogenous population composed of Mexican immigrants began to incorporate another group of native Spanish-speakers, Puerto Rican immigrants. Like the Mexicans before them, Puerto Ricans first came to Indiana during the late 1940 s as contract labor for US Steel, to fill the labor shortage 
that occurred as a result of World War II (Maldonado, 1987). With the migration of a new group of Latinos came some competition between community groups for Mexican and Puerto Rican immigrants in terms of political clout. Mexican-Americans in the Region began to organize political clubs starting in 1938 to encourage political participation by members of their community. As a result of the increased migration of Puerto Ricans during the later 1940s and early 1950s, competing community and political organizations emerged, even though they shared many of the same concerns for their constituencies (Allsup, 1987). There were several attempts at unifying these organizations over the years that followed, the most successful of which became the Concerned Latins Organization (CLO), which was active during the early 1970s in community empowerment of the Region's Latinos, pursuing concerns of housing, employment, and education. For the most part, the CLO and other Latino political organizations in the Region that preceded it did not become overtly concerned with language planning and policy, focusing rather on increasing the political power of the Latino community through heightened political participation.

\section{Moving Beyond the Region}

In rural, southern, and central parts of Indiana that lie outside of the urban industrial areas of Gary and East Chicago, immigration of Latinos has been less welldocumented and investigated, due to the fact that many Latinos living in these areas arrived as migrant workers. As such, they often moved either within or to and from Indiana quite frequently without establishing permanent homes in the towns, cities, and rural locations where they came to work. Thus they were not normally included in US census data or other statistical reports (Aponte, 2001). By the 1970s and 1980s, Latino communities began to develop in areas of the state outside of the Region, including South Bend, Fort Wayne, and Indianapolis, as evidenced by the emergence of Latino community organizations during this era. However, these groups tended to be more scattered, and scant research on their activities exists, especially concerning language planning and policy. The statewide Latino population explosion has really occurred during the last two decades, and these more recent data will be examined in the following section.

\section{Latino Presence in Indiana-1990-present}

Beginning in the early 1990s, the Latino population in Indiana started a trend of rapid expansion that continues today. Much like the early immigrants to the northwest region of the state, the vast majority of Indiana's Latinos are of Mexican origin, and it is estimated that many of them migrate from other parts of the US (i.e., the South or Southwest) rather than directly from their countries of origin (Levinson, Everitt, \& Johnson, 2007). The statewide growth in the Latino population as a whole is illustrated in the following table, with data from the US Census Bureau (Chapa, Saenz, Rochin, \& Diaz McConnell, 2004; US Census Bureau, 2010a): 


\begin{tabular}{|c|c|c|c|}
\hline & 1990 Census & 2000 Census & 2010 Census \\
\hline $\begin{array}{l}\text { Total } \\
\text { Population }\end{array}$ & $5,544,156$ & $6,080,485$ & $6,483,802$ \\
\hline $\begin{array}{l}\text { Latino } \\
\text { Population }\end{array}$ & 98,789 & 214,536 & 389,707 \\
\hline
\end{tabular}

Table 1: Indiana Population Totals and Latino Population Totals

While the total population of Indiana experienced a $9.7 \%$ rate of growth between the 1990 and 2000 censuses, the Latino portion of Indiana's population grew by $117 \%$. This expansion continues, as the Latino population increased by $45 \%$ between 2000 and 2010, compared with only a 6\% increase for the total population. The growth has occurred in nearly all areas of the state, with the largest growth patterns concentrated in urban areas, such as Fort Wayne and Indianapolis, and also in the northwest region. Notable are Marion County, home to Indianapolis and outlying suburbs, Tippecanoe County, home of Lafayette and Purdue University, and Allen County, home of Fort Wayne, all three of which lie outside of the Region and which saw huge increases in their Latino populations within the period between 1990 and 2000 (STATS Indiana, 2009). Marion County, in particular, continues to experience the most rapid increase in Latino population of any county in the state, with the number of Latinos nearly quadrupling from 8,450 to 33,290 between 1990 and 2000 (Aponte, 2001). The top 8 counties in Indiana in terms of the size of their Latino populations are primarily those that experienced the most growth between 1990 and 2000, including, in order, Lake, Marion, Elkhart, Allen, St. Joseph, Tippecanoe, Porter, and Kosciusko. Only three counties experienced a decline in Latino population during this time period (STATS Indiana, 2009).

Similar to the early Latino immigrants to Indiana, those who have arrived more recently are overwhelmingly of Mexican origin, with others from various Spanish-speaking Caribbean, Central, and South American nations. Nearly $82 \%$ of Indiana's foreign-born Latinos were born in Mexico, another 8\% or so come from Central American nations, such as El Salvador or Guatemala, about 4\% come from Caribbean countries, and the remaining 6\% are from South America, mainly Peru and Venezuela (Conover, Rogers \& Kinghorn, 2005). As a result of this, much of the existing research concerns issues specific to the Mexican-origin sector of Indiana's Latino community, since it is so large compared to those of other national origins.

Aside from the significant growth in the Latino population between 1990 and 2010, it is also necessary to highlight some salient characteristics of this population that will become more relevant in the forthcoming investigation of Indiana's language policies. As previously stated, the primary focus here will be on status planning and acquisition planning for languages as they affect Indiana's Latinos. Since educational institutions are primary sites for language acquisition planning, (Cooper, 1989), it may be useful to highlight the percentage of Latinos in the state who are or will be of an age to attend school. According to US Census data (2010b), 141,464 Latinos in Indiana are under the age of 18. That is over one third of the total Latino population. For the state's population as a whole, less than $25 \%$ are 18 or 
younger. Judging by these data, high proportions of Indiana's entire Latino population either are or will be attending schools, where it is very likely that many of their peers and teachers will be monolingual English speakers.

In addition to underscoring data on the ages of Latinos in Indiana, it will also be useful to distinguish some of their linguistic characteristics, since identifying oneself as Latino on a survey or in the Census does not necessarily indicate fluency in Spanish or lack of fluency in English. US Census data (2010c) indicates that about two thirds of Indiana's Latinos over the age of five speak Spanish at home, and about half of those who speak Spanish in the home speak English "less than very well." This recent data is echoed by previous research, as well, indicating that this trend is ongoing (Conover, Rogers, \& Kinghorn, 2005). Therefore, issues of language planning and policy are extremely salient to the Latino population in Indiana, with high proportions of young people who either are or will be attending schools, in addition to the half of the population that is not proficient in English.

With the historical context of Indiana's Latinos and the data on their more recent and current situations in mind, the following section will explore the history of language planning and policy practices in Indiana as they affect Latino communities.

\section{Language Planning and Policy in Indiana-State and Community Levels}

\section{Language in Government}

With a total state population that is still overwhelmingly composed of native speakers of English, as only 8\% of Hoosiers over age 5 speak a language other than English at home, it may seem that Indiana has had little need for establishing an "official" language (US Census Bureau, 2010d). However, the Indiana Code, the set of laws established by the General Assembly, does include an official policy on language for the state. According to Indiana Code 1-2-10-1, "The English language is adopted as the official language of the state of Indiana." This section was added to the Indiana Code by the General Assembly in 1984, and it goes no further than this one simple sentence. English is not specifically designated here as the exclusive language of government, business, or educational instruction, nor is it indicated whether or how this law should be enforced. In their study of language and education policy in Indiana, Simich-Dudgeon \& Boals (1996) suggest, "the most important function of the [English-only] law seems to be to serve as a symbol of state unification and of the collective history and traditions of the people of Indiana" (p. 551). Since this law lacks specificity and does not seem to be enforced, its power as a symbol of a unified, English-speaking state may not be so strong. It may serve as a relic of a more culturally and linguistically homogeneous era in Indiana, but as a little-known portion of the Indiana Code, it may not really affect other state policies and practices. While recent developments in immigration law in Indiana, including attempts to promote strict law enforcement policies that would impact undocumented immigrants, do warrant mention here, as they reflect the social and political climate affecting Latino immigrants, the discussion of this law and its legal challenges lies outside the scope of this paper. Rather, this inquiry continues with an 
examination of some other state and community level initiatives and practices that will paint a clearer picture of language planning and policies for Indiana's Latino population.

\section{Government-Sanctioned Language Policies in Action}

While the state's legal code may assert that English is the official language of Indiana, a variety of organizations and services reveal that Spanish is at least recognized as a valid and even necessary form of communication. By browsing the website for the Indiana government, it becomes evident that in some cases, the state does attempt to reach out to the Spanish-speaking Latino community by offering documents translated into Spanish, and some translation services. However, the website may be difficult to navigate for someone with little or no English fluency, since there is no text in Spanish on the home page (State of Indiana, 2012). It is only through clicking on the help button that one can find a link called "Información de Indiana," which leads to several documents translated into Spanish and one more website in Spanish. The documents consist of a directory of phone numbers for state agencies, facts about Indiana, a guide for potential business owners, and a welcome letter, including several additional listings for phone numbers and websites linked to information regarding taxes, license branches, and state recreation opportunities. The additional website is part of the state's court system, providing forms, telephone numbers, and descriptions of procedures for legal actions translated into Spanish (Indiana Courts, 2012).

Along with the translated documents and websites for native Spanish speakers, the government website links to a couple of available language-related services. The Indiana Judicial Center, in cooperation with Ivy Tech, offers "workplace Spanish" courses to "any employee in the State of Indiana who directly reports to a judicial officer of a trial court of record or employees of the Clerk's office assigned to work with the courts" (Indiana Judicial Center, 2012). These courses are designed for court employees to become proficient in beginning Spanish, learning things such as greetings, directions, and how to explain legal proceedings. For some employees, who must be authorized by their departments, the course will be free of charge, while others must pay out of their own pockets to take the course. It is unclear whether there would be any tangible benefit to the employee (i.e., a pay increase or job promotion) as a result of completing this course, but it may provide access to employment in a wider range of communities, including those with higher concentrations of native Spanish speakers.

For Spanish speakers, the state website also lists locations where they may receive free assistance in Spanish in preparing their taxes. This list may not be exhaustive, as many communities may offer services through their own volunteer or community organizations: there are only locations listed in Indianapolis, Lafayette, Merrillville, and Bloomington (Indiana Commission on Hispanic/Latino Affairs, 2012). The ICHLA, which is the aforementioned organization providing the information on Spanish language assistance for tax preparation, acts as the umbrella organization for the state in research, planning, and recommendation of policies and 
practices that affect the Latino population. The goals and initiatives of the ICHLA are quite varied, with the overarching theme of bridging cultural gaps between Indiana's Latino and non-Latino communities through increasing cultural competence on both sides and promoting greater social and economic equity (ICHLA, 2011). The ICHLA's Strategic Plan for 2011-2012 lists a series of five "challenges" faced by Indiana's Latino community, as well as objectives and strategies that will be implemented to address these challenges. Several of the strategies proposed to address the various challenges include elements of language planning. For example, the first challenge identified by the ICHLA is "Qualified child care availability and child care business development" (ICHLA, 2011). Essentially, policymakers want to help ensure that Latino families have information about and access to quality child care, as well as to aid Latino child care providers in the process of becoming certified. Strategies proposed to help tackle this challenge include providing English-language development courses to Latino child care providers to help them navigate the certification process, as well as creating an ICHLA partnership with another state agency to provide Spanish-language workshops for families seeking child care (ICHLA, 2011). These are examples of both acquisition and status planning for Spanish and English: English courses for child care providers will expand the number of English speakers within this community, while offering Spanish-language workshops for parents sends the message that this important information should be available in both Spanish and English. Two more of the five listed challenges in ICHLA's 2011-2012 Strategic plan, curbing recidivism among Latino youth and increasing school readiness, also include strategies that focus on language planning, such as Spanish-language public service announcements around important programs and current issues. The existence of the ICHLA as an arm of the state government, along with the various state websites and services available in Spanish indicate the recognition of Indiana's Spanish-speaking Latinos as an important minority group with a variety of concerns to be addressed, and as the ICHLA's Strategic Plan (2011-2012) illustrates, language planning is often one method of addressing these challenges.

\section{Implications of State-Level Language Policies and Practices for Indiana's Latinos}

Although the evidence of explicit language planning and implementation of any official language policies by the state government is relatively scant, the few previously mentioned examples may reveal some prevalent attitudes and values held by those in power regarding language status and acquisition. Many of the translated documents and websites widely available provide information for Spanish speakers on how to comply with common procedures, laws, and regulations. The two most prominent cases are those of the tax preparation assistance and the plethora of information available around the judicial system. By offering free and state-sponsored sites, few and far between though they may be, where Spanish-speakers may receive help in filling out their tax forms, the government sends the implicit message to the Latino population that their tax dollars are, indeed, quite important. In much the same way, the state's court system 
clearly values its role in the lives of Indiana's Spanish speakers, as this is the only example of a state agency offering to pay for Spanish classes for its English-speaking employees, at least as indicated by the state's website. There were also many more translated documents and websites linked to the Indiana judicial system with information for Spanish speakers who may need to appear in court or become otherwise involved in legal matters. Here, it seems clear that the courts wish to ensure that those who do not speak English may still have an understanding of legal procedures, either through online documents or through court employees who have gained a beginning knowledge of Spanish. These two examples of language planning and policy at the state level do not necessarily demonstrate a rise in the level of status for Spanish or an emphasis on Spanish acquisition for English speakers. Rather, they show the areas in which communication in the native language has been deemed necessary, in order for Spanish speakers to conform to laws and procedures that the state considers to be important. As stated in the Indiana code, English remains the "official" language of Indiana, and the de facto language of law and government, in spite of some efforts to accommodate native Spanish speakers.

In order to provide a glimpse into how the government's policies and practices around language status and acquisition affect a portion of Indiana's Spanish-speaking population, evidence will be cited from a recent study of ESL and language services in one rural Indiana county (Pawan \& Thomalla, 2005). While the overall population of this county is rather small, at 14,000 , and the Latino portion is only about $1 \%$, planning for language is still an important task for many in business, education, and local government. In their research of the kinds of language services that were being offered to the Latino immigrant community, Pawan \& Thomalla (2005) found that many services were quite scattered and showed little evidence of any planning. For example, interpretation services for Spanish speakers in hospitals, courts, and even schools were often provided only on an ad-hoc basis by untrained bilingual staff or volunteers. Several of the largest employers in the county did provide free ESL classes to their Spanish-speaking staff, but sometimes classes were not well attended due to their inconvenient sites or times. Two of these companies also offered beginning Spanish classes to their management staff, but employees were responsible for paying for these courses. This study of one rural Indiana county demonstrates that the lack of language planning and clear language policy at the level of the state government trickles down to adversely affect local governments, where inconsistent planning results in rather spotty language services for native Spanish-speakers.

\section{Language Planning and Policy in Indiana Schools}

While the examples of language planning and policy implementation for Indiana's native Spanish-speaking population at the government level are sparse, educational systems and institutions provide for many more official and unofficial illustrations of status, and especially of acquisition, planning. As this study focuses on schools as main sites for implementation of policies regarding language acquisition, it will be useful to consider relevant legal decisions, both at federal and state levels, which help to determine language policies for educational institutions. Although education 
is officially to be legislated and managed by the government of each state, several pieces of federal legislation influence how this takes place. Beginning with Title VI of the Civil Rights Act of 1964, no federally funded agency (including public schools) may discriminate on the basis of sex, race, or national origin. While this statute may not explicitly prohibit discrimination on the basis of native language, the portion of it dealing with national origin may apply to this kind of discrimination, since so many Spanish-speaking Latinos hail from other nations. Shortly following the Civil Rights Act was the Bilingual Education Act or Title VII of the Elementary and Secondary Education Act (ESEA) of 1968, and reauthorized in 1994, which stated that schools must provide supplementary educational programs to address the needs of culturally and linguistically diverse students. On the heels of this came Lau v. Nichols in 1974, wherein the US Supreme Court ruled that failing to provide supplementary language services and education to children who spoke a first language other than English was, in fact, discrimination on the basis of national origin. More recently, the Bilingual Education Act has been replaced with Title III of the No Child Left Behind Act of 2001, which shifts the focus from bilingual educational programs to an emphasis on English acquisition for students who do not speak English as a native language. In order to comply with these pieces of legislation and the aforementioned Supreme Court decision, Indiana schools must accommodate their Spanish-speaking Latino students with some level of extra service for language education.

Possibly in response to the Lau v. Nichols decision, Indiana lawmakers passed House Enrolled Act 1324 in 1976, modeled closely after the earlier federal Bilingual Education Act. The goal of HEA 1324 was twofold and somewhat contradictory: to prepare non-English-speaking students for full participation in mainstream classrooms while also providing bilingual and bicultural education to value the home language and culture. This measure was passed due to some pressure from the Concerned Latinos Organization (CLO) of northwest Indiana, which thought it necessary that Indiana schools begin to address the needs of Latino students. In spite of the inclusive language and lofty goals of HEA 1324, it has never helped Indiana's Latino students to gain better educational opportunities, because the General Assembly has never appropriated funds towards its enactment (SimichDudgeon \& Boals, 2001). The goal of bilingual/bicultural education for Latino students remains largely symbolic, with current practices and policies demonstrating a very different stance towards language acquisition.

\section{The Current Situation-Latinos in Indiana's Schools}

Before outlining the language policies currently implemented for students in Indiana's public schools, it is necessary to show the demographic context of schoolaged Latinos in this state. Similar to the population of the state as a whole, the Latino population in public schools has been growing quite rapidly over the last couple of decades. The following graph illustrates the growth in the number of Limited English Proficiency (LEP) students over several years. While not all LEP students in Indiana speak Spanish as a native language, the vast majority $(79 \%)$ of 
them do, so this chart may be a fairly valid indicator of Latino population growth. Data are from the Indiana Department of Education (2012a).

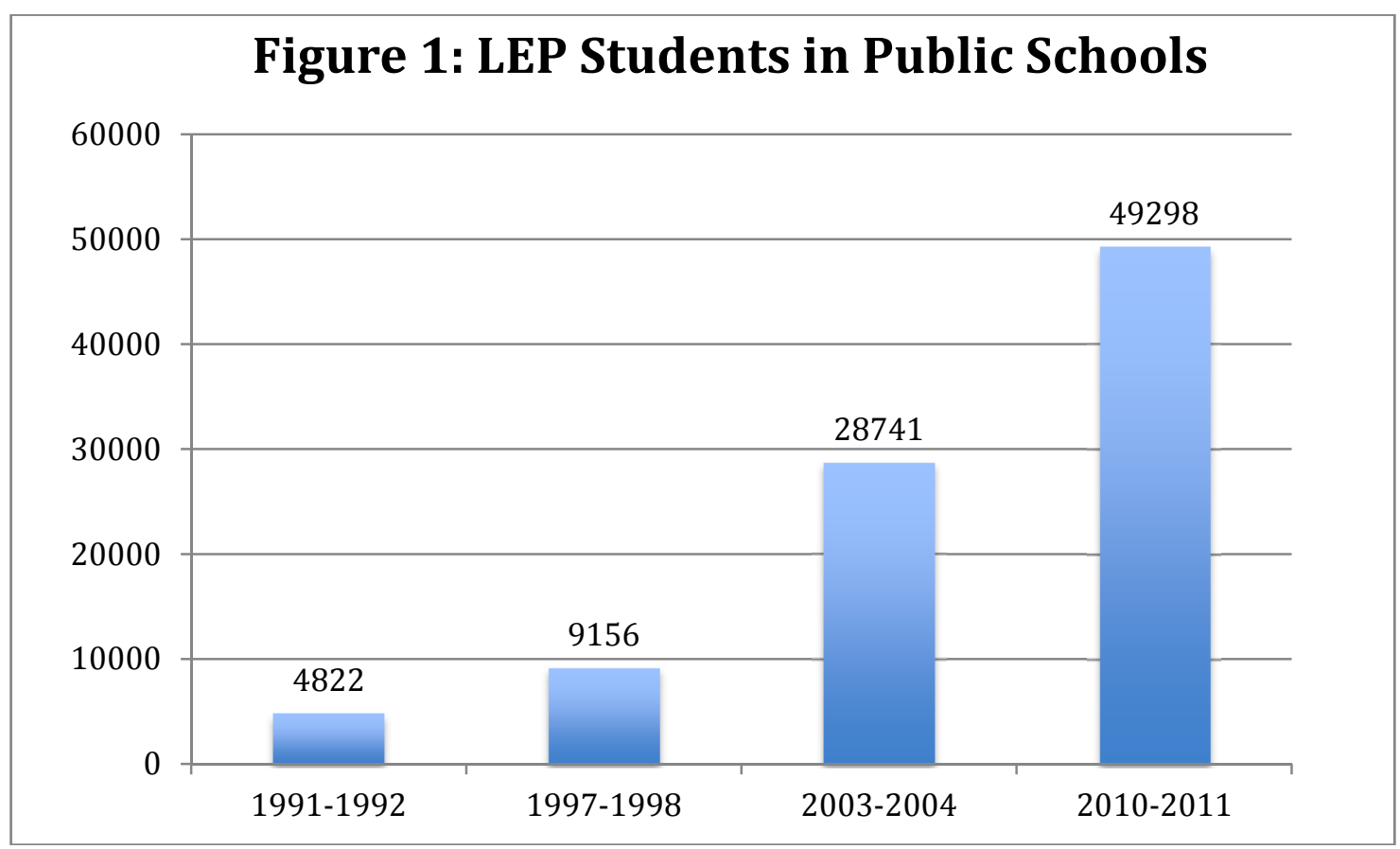

As evidenced by these data, the population of LEP students, and thus of Spanishspeaking Latinos, in public schools in Indiana has grown exponentially over the course of the last twenty years, with nearly 50,000 LEP students in the state as of the most recent school year for which data are available. As of the 2010-2011 school year, $8.4 \%$ of public school students in Indiana were Latino, and nearly $5 \%$ of all students were identified as LEP (Indiana Dept. of Education, 2012a). Indianapolis Public Schools, which is also the largest school district in the state, has the greatest number of LEP students (Indiana Department of Education, 2012b). These trends and statistics mirror the demographics of the state's Latino population, with the benefit that schools track data not only on race and ethnicity of their students, but also on their language proficiency.

Since Indiana schools are currently serving many more Latino and LEP students than previously, they have adopted policies and practices to address their educational and language needs. Much like the vague language of the "official" English policy in Indiana, the Indiana Academic Code, which serves as the legal outline for how public schools must operate in this state, does not provide much clarity on how education for English language learners should take place. The Code states "[e]ach school corporation shall provide appropriate instruction to limited English proficient students" (511 IAC 6.1-5-8). On one hand, this leaves significant flexibility to diverse school districts, some of which might have high proportions of LEP students, and some of which might have none. However, this rather ambiguous statement leaves open to question what "appropriate instruction" might entail, and many school administrators could interpret this in very different ways. The state's 
Department of Education does include an Office of English Language Learning and Migrant Education, which serves as a resource for guidelines for the identification, instruction, and assessment of ELL students, simply ensuring that state-level procedures are aligned with federal requirements (Indiana Dept. of Education, 2012c).

Besides creating the Office of English Language Learning and Migrant Education, Indiana also designates funding for "Non-English Speaking Programs," (NESP) for districts and schools that serve students whose first language is not English. These NESP funds are meant to serve as a supplement to federal funding for Title III of NCLB, which may be spent in very limited ways. According to the Indiana Urban Schools Association ESL Collateral Group (2009), NESP funds are generally used to provide salaries for ESL teachers, translation of school documents into Spanish, ESL curricular materials, and professional development for teachers. NESP funds are often inadequate for providing any sort of additional programs, such as bilingual or dual-language classrooms.

\section{Implications for Language Policies and Practices in Education for Indiana's Latinos}

While remaining compliant with federal legislation and court rulings regarding education for students with limited English proficiency, Indiana's government and Department of Education have shown through their policies and practices regarding language in education that English will continue to be the most important language for accessing the best instruction in most of Indiana's public schools. Simply examining the language used to describe the laws and organizations concerned with these issues reveals much. Rather than using terms such as multicultural, bilingual, or diversity, the state lawmakers have designated the Office of English Language Learning and Migrant Education, along with Non-English Speaking Program funding. The Indiana Academic Code refers to "appropriate instruction for limited English proficient students," and those NESP funds to provide that instruction almost always allow for an ESL teacher, rather than bilingual staff. Clearly, those in power in the state government value English acquisition for Latino students and seem to be doing little in terms of helping these students to maintain and develop their native language or to preserve their cultural heritage.

\section{Local Language Planning and Policies in Community Organizations}

Since much of the research and evidence examined thus far has dealt with language planning and policy at the government or institutional levels, it may be useful to briefly investigate the recent work and presence of Latino community organizations in Indiana to determine how they address issues of language planning for those involved. The Indiana Latino Institute is one of the largest organizations for helping to address the needs of Indiana's Latino community, and bills itself as "the leader in the Latino community in Indiana for advocacy, resource and referral, research and community assessment and model program development for Latino adults and youth" (ILI, 2012). According to its website, the ILI also offers translation services between English and Spanish, but besides hosting a website that is available in 
either Spanish or English, that is the only indication of a concern with language planning. It seems that the ILI may be a means to learn about other organizations and resources of the Latino community around the state. Another one of these is La Plaza, a Latino community organization based in Indianapolis. According to their website, they offer scholarships to Latino students, summer and school-year enrichment programs, and translation services (La Plaza, 2012). An hour south of Indianapolis, Su Casa Columbus offers similar interpretation and translation services, in addition to classes in both Spanish and English for community members and a Spanish language newspaper (Su Casa Columbus, 2012). Levinson, Everrit, \& Johnson (2007) found that comparable community organizations for Latinos also exist in Noblesville, Fort Wayne, Bloomington, and Martinsville. These local advocacy organizations serve to provide assistance to both Latinos and other community members in increasing cultural awareness, and especially in helping Latinos to adapt to linguistic and cultural differences. While these organizations serve important purposes to their communities and likely help to improve the lives of Latinos within their communities, their services may not be as frequent or as permanent as those offered by governmental institutions. As Levinson et al. (2007) point out, these nonprofit centers "must constantly justify their activities and search for ongoing funding. They are especially vulnerable to political trends and economic downturns" (11). As sites where language planning is certainly taking place, in the form of language classes, translation services, and even Spanish-language publications, these Latino community organizations may have tremendous influence on cross-cultural attitudes in the communities they serve. However, further research is necessary to determine how effectively they are meeting their goals and how their practices affect planning for language status and acquisition.

\section{Conclusion}

This review of the literature and of some available data regarding language planning practices and policies in Indiana has revealed that while state and community organizations are beginning to address issues of diversity in language and culture between Indiana's Latinos and non-Latinos, there is still much work to be done. As the recent US Census data has shown, the Spanish-speaking Latino population in Indiana has grown rapidly in recent years. Several state agencies, such as the Judicial Center, have begun to offer services and translation to meet the needs of Latino community members. School districts have also been mandated by both federal and state legislation to offer supplementary educational services to Latino students, which usually include some form of ESL instruction. Localized community organizations across the state offer classes and translation services, as well, in hopes of bridging the cultural gaps that may exist between Latinos and non-Latinos. In all of these cases, the evidence of explicit language planning and policy implementation is somewhat scattered. While Indiana's official language is designated as English, this law has been unenforced and serves as a symbol more than a binding rule. However, English continues to hold its status as a more valuable language than Spanish for Indiana's Latinos, as evidenced by the consistent emphasis on English acquisition in education and the relative lack of focus on Spanish acquisition for either educators or government officials. Spanish 
speakers are bringing valuable and diverse cultural and linguistic resources with them to Indiana, and these resources might disappear if educational institutions, government agencies, and community organizations fail to utilize and value them. It seems that part of the solution may lie in more intentional and explicit planning for language status and acquisition for native Spanish speakers in Indiana, so that their native language may increase in functionality here, and begin to be acquired and maintained by a broader spectrum of people.

\section{References}

Allsup, C. (1987). Concerned Latins Organization. In J. B. Lane \& E. J. Escobar (Eds.), Forging a community: The Latino experience in northwest Indiana (pp. 251262). Chicago: Cattails Press.

Aponte, R. (2001). Latinos in Indiana: Growth, distribution, and implications. Statistical Brief No. 14. East Lansing, MI: The Julian Samora Research Insititute, Michigan State University.

Bilingual Education Act. (1994). Pub. L. No. 103-382, The Improving America's Schools Act of 1994.

Chapa, J., Saenz, R., Rochin, R. I., \& Diaz McConnell, E. (2004). Latinos and the changing demographic fabric of the rural midwest. In A. V. Millard and J. Chapa (Eds.), Apple pie \& enchiladas: Latino newcomers in the rural midwest (pp. 47-74). Austin: University of Texas Press.

Conover, J., Rogers, C., \& Kinghorn, M. (2005). Indiana's Latino population: Demographic and economic perspectives [PDF Document]. Indiana Business Research Center: Kelley School of Business, Indiana University. Retrieved from www.ibrc.indiana.edu/briefs/Latinos-Apr07.pdf.

Cooper, R.L. (1989). Language planning and social change. New York: Cambridge University Press.

Escobar, E. J. (1987). The forging of a community. In J. B. Lane \& E. J. Escobar (Eds.), Forging a community: The Latino experience in northwest Indiana (pp. 3-24). Chicago: Cattails Press.

Garcia, J. R., \& Cal, A. (1987). El Circulo de Obreros Catolicos San Jose, 1925-1930. In J. B. Lane \& E. J. Escobar (Eds.), Forging a community: The Latino experience in northwest Indiana (pp. 95-114). Chicago: Cattails Press.

Indiana Academic Code. (2009). 511 IAC, 6.1-5-8.

Indiana Code. (1984). Ch. 10. Sec. 1. 1-2-10-1. Official Language of the State.

Indiana Commission on Hispanic/Latino Affairs. (2011). Strategic Plan, 2011-2012. Retrieved from http://www.in.gov/ichla/files/2011.2012 ICHLA STRATEGIC PLAN WEB.p df. 
Indiana Commission on Hispanic/Latino Affairs. (2012). Spanish-Assisted Indiana Tax Preparation Sites. Retrieved from http://www.in.gov/ichla/2416.htm.

Indiana Courts. (2012). Indiana Judicial Branch, Self Service Legal Center: Formularios de la Corte. Retrieved from http://in.gov/judiciary/selfservice/2365.htm.

Indiana Department of Education. (2012a). State of Indiana: Enrollment Overview. [Data Set]. Retrieved from http://compass.doe.in.gov/dashboard/enrollment.aspx?type=state.

Indiana Department of Education. (2012b). Indianapolis Public Schools: Enrollment Overview. [Data set]. Retrieved from http://compass.doe.in.gov/dashboard/enrollment.aspx?type=corp\&id=5385.

Indiana Department of Education. (2012c). English Learning and Migrant Education Programs. Retrieved from http://www.doe.in.gov/achievement/englishlearners.

Indiana Judicial Center. (2012). WorkPlace Spanish Training for the Indiana Judicial System. Retrieved from http://www.in.gov/judiciary/center/2411.htm.

Indiana Latino Institute. (2012). Vision Statement. Retrieved from http://indianalatino.com/english/index.html.

Indiana Urban Schools Association ESL Collateral Group. (2009). Proceedings from Meeting on February 12, 2009 at MSD Washington Township.

La Plaza, Inc. (2007). Programs. Retrieved from http://www.laplaza-indy.org/programs/index.php.

Lane, J. B. (1987). Extranjeros en la patria. In J. B. Lane \& E. J. Escobar (Eds.), Forging a community: The Latino experience in northwest Indiana (pp. 25-32). Chicago: Cattails Press.

Lau v. Nichols, 414 US 563. (1974).

Levinson, B. A. U., Everitt, J., Johnson, L.C. (2007). Integrating Indiana's Latino Newcomers: A Study of State and Community Responses to New Immigration. CES Working Paper Series: Working Paper \#1. Center for Education \& Society.

Maldonado, E. (1987). Contract labor and the origins of Puerto Rican communities in the United States. In J. B. Lane \& E. J. Escobar (Eds.), Forging a community: The Latino experience in northwest Indiana (pp. 201-214). Chicago: Cattails Press.

No Child Left Behind Act. (2001). Pub. L. No. 107-110.

Pawan, F. \& Thomalla, T. G. (2005). Making the invisible visible: A responsive evaluation study of ESL and Spanish language services for immigrants in a small rural county in Indiana. TESOL Quarterly, 39(4), 683-705. 
Rosales, F. A. \& Simon, D. T. (1987). Mexican immigrant experience in the urban Midwest: East Chicago, Indiana, 1919-1945. In J. B. Lane \& E. J. Escobar (Eds.), Forging a community: The Latino experience in northwest Indiana (pp. 137-160). Chicago: Cattails Press.

Simich-Dudgeon, C. \& Boals, T. (1996). Language and education policy in the state of Indiana: Implications for language minority students. TESOL Quarterly, 30(3), 537-555.

State of Indiana. (2012). Official Website of the State of Indiana. Retrieved from http://in.gov/.

STATS Indiana. (2009). Growth in Hispanic population, 1990-2000. [Data set]. Indiana Business Research Center, Kelley School of Business, Indiana University. Retrieved from http://www.stats.indiana.edu/maptools/maps/thematic/c2k bycounty/gro wth hisp.gif.

$\mathrm{Su}$ Casa Columbus. (2009). A Bilingual, Bicultural Center for the Community. Retrieved from http://www.sucasacolumbus.com/.

Title VI of the Civil Rights Act. (1964). 42 U.S.C. § 2000d et seq.

US Census Bureau. (2010a). 2010 Census interactive population search: Indiana. [Data set]. Retrieved from http://2010.census.gov/2010census/popmap/ipmtext.php?fl=18.

US Census Bureau. (2010b). Sex by age (Hispanic or Latino). [Data set] Retrieved from http://factfinder2.census.gov/faces/tableservices/jsf/pages/productview.xh tml?pid=ACS 10 5YR B01001I\&prodType=table.

US Census Bureau. (2010c). Language spoken at home by ability to speak

English for the population 5 years and over (Hispanic or Latino). [Data set]. Retrieved from http://factfinder2.census.gov/faces/tableservices/jsf/pages/productview.xh tml?pid=ACS 10 1YR C16006\&prodType=table.

US Census Bureau. (2010d). Language spoken at home. [Data set]. Retrieved from http://factfinder2.census.gov/faces/tableservices/jsf/pages/productview.xh tml?pid=ACS 10 1YR S1601\&prodType=table. 